

Original Research Article

https://doi.org/10.20546/ijcmas.2019.806.076

\title{
Floral Biology of CMS Lines in Chilli
}

\author{
M. Vinodhini*, V.V. Dalvi, S.S. Desai, S.G. Bhave and S.G. Mahadik \\ Department of Agril. Botany, College of Agriculture, Dapoli, Dr. Balasaheb Sawant Konkan \\ Krishi Vidyapeeth, Dapoli- 415712 (M.S.), India \\ *Corresponding author
}

\section{A B S T R A C T}

\begin{tabular}{|l|l|l|l|l|l}
\hline Keywords & $\begin{array}{l}\text { Cytoplasmic Male sterility (CMS) is increasingly utilized for hybrid seed production of } \\
\text { chilli (Capsicum annuum L.). Eight CMS and eight maintainer lines were studied for } \\
\text { biology, Variability }\end{array}$ & $\begin{array}{l}\text { different morphological characters and pollen sterility. The CMS lines viz., AVPP0711S, } \\
\text { AVPP0709S, AVPP0710S, AVPP0309S and AVPP0310S were found to be most sterile. It } \\
\text { has been concluded that wide range of genetic variability existed for the different floral } \\
\text { biological and morphological characters which could be utilized for systematic exploration }\end{array}$ \\
\cline { 1 - 2 } Article Info & $\begin{array}{l}\text { in chilli improvement programme through hybridization. Improvement programme would } \\
\text { greatly benefit from the knowledge of floral biology gained during the present } \\
\text { investigation. }\end{array}$ \\
\hline $\begin{array}{l}\text { Available Online: } \\
\text { 10 June 2019 }\end{array}$ & \\
\hline \hline
\end{tabular}

\section{Introduction}

Chilli (Capsicum annuum L.) $(2 \mathrm{n}=24)$ is considered as one of the most important commercial spice crop. The knowledge of floral biology is a pre-requisite for embarking upon a crop breeding and hybridization programme. Chilli (Capsicum annuum L.) is one of the crops where time of anthesis and dehiscence, pollen viability and germination and stigma receptivity changes over different locations (Kalloo, 1994). Moreover, in this crop, normally fruits are not formed from all the flowers produced. We can increase our yield by higher fruit setting with the knowledge of exact floral biology and seasonal effects. Male sterility is extensively utilized in chilli for the development of hybrids. Presently in chilli, genetic male sterility (GMS) and cytoplasmic-genetic male sterility (CGMS) have been commercially exploited for the development of hybrids. Though the cytoplasmic male sterility has several advantages, it has some disadvantages too. These lines are highly sensitive to the environmental conditions resulted in pollen production which leads to selfing. Therefore emphasis has to be given to develop region specific indigenous male sterile lines, which should be good for important floral traits, supporting male sterility along with agronomical traits.

\section{Materials and Methods}

A total of eight CMS lines viz., AVPP0309S, AVPP9907S, AVPP0310S, AVPP0516S, AVPP0517S, AVPP0710S, AVPP0709S, 
AVPP0711S and their maintainer lines AVPP0309, AVPP9907, VI060629:C05601, VI037614: TC0630, VI060632: C05661, VI046838: TC0667, VI060627: C05606 and VI060630: C05671 respectively were utilized for the floral and morphological characters study.

These eight CMS lines and their maintainer counterparts were obtained from AVRDC-The World Vegetable Centre, Taiwan. In the month of November 2014, seeds were sown in the nursery trays. In the month of December, the seedlings were transplanted in black polythene bags. The plants were tagged for recording detailed observations such as Days to first Flowering, Time of flower opening, Time of dehiscence, Pollen sterility (\%), Pollen viability (\%)' Number of pollen grains/anther, Receptivity of stigma, Structure of ovary, Number of flowers per plant, Plant height at maturity $(\mathrm{cm})$ and Number of branches/ plant.

\section{Results and Discussion}

From present study, it was found that CMS lines possessed a great deal of variation for pollen and morphological characters. The data of morphological traits of chilli genotypes are given in the Table 1 .

\section{Days to first flowering}

In the present investigation, days to first flowering ranged from 63.33 to 83 days and the lines differed significantly for the days to first flowering. This was in supports with finding Sudré et al., (2010) in Capasicum spp.

\section{Number of flowers per plant}

Number of flowers per plant is the most vital character as ultimately it is the flower which bears fruit that leads to yield. In the present investigation, the number of flowers per plant ranged from 90.33 to 185.33 exhibiting a wide range of variation for this character. Highest number of flowers was recorded by AVPP0709S (185.33) followed by AVPP9907S (163.33).

\section{Pollen sterility}

Pollen sterility ranged from 0 to 99 per cent. In case of CMS lines pollen sterility was high ranging from 78.42 to 99 per cent. Insignificant number of viable pollen was associated with the CMS lines.

There should be always $100 \%$ pollen sterility and that line can be used as a CMS line. AVPP0711S line showed 99\% pollen sterility. It has been observed that at low temperature, meiotic breakdown is either completely stopped or delayed, resulting in pollen fertility. This is also reported by Kumar et al., (2007) and Shifriss (1997) in Pepper (Capasicum annuum L.).

\section{Pollen viability}

In the maintainer lines the pollen viability ranged from 59.84 to $100 \%$. This was in supports with the findings of Saxena et al., (2003) in chilli (Capasicum annuum L.). Overall CMS lines showed some breakdown of sterility and inheritance was not stable, affected by the environment. Similar results were obtained by Ma et al., (2013) in pepper (Capsicum annuum).

\section{No. of pollen grains per anther}

The probability of occurrence of fertilization would increase with the number of pollen grains. More the pollen grains more should be the chances of fertilization. In the present investigation, the mean pollen production per anther was 6464.09. The pollen production ranged from 388.89 to 22380.95 . 
Table.1 Morphological traits of chilli genotypes

\begin{tabular}{|c|c|c|c|c|c|c|c|c|c|}
\hline $\begin{array}{l}\text { Sr. } \\
\text { no }\end{array}$ & Strain & $\begin{array}{c}\text { Days to } \\
\text { first } \\
\text { flowering }\end{array}$ & $\begin{array}{c}\text { Number } \\
\text { of } \\
\text { flowers } \\
\text { pet plant }\end{array}$ & $\begin{array}{c}\text { Pollen } \\
\text { sterility } \\
(\%)\end{array}$ & $\begin{array}{c}\text { Pollen } \\
\text { fertility } \\
(\%)\end{array}$ & $\begin{array}{l}\text { Number of } \\
\text { pollen } \\
\text { grains per } \\
\text { anther }\end{array}$ & $\begin{array}{c}\text { Height } \\
\text { (cm) }\end{array}$ & $\begin{array}{c}\text { Number of } \\
\text { primary } \\
\text { branches } \\
\text { per plant }\end{array}$ & $\begin{array}{c}\text { Number of } \\
\text { secondary } \\
\text { branches per } \\
\text { plant }\end{array}$ \\
\hline 1 & AVPP0309S & 72.00 & 139.33 & 92.21 & 7.79 & 500.00 & 29.33 & 3.67 & 6.33 \\
\hline 2 & AVPP9907S & 79.67 & 163.33 & 83.76 & 16.24 & 611.11 & 90.67 & 3.33 & 7.33 \\
\hline 3 & AVPP0310S & 72.00 & 95.67 & 90.48 & 9.52 & 388.89 & 65.00 & 2.33 & 4.33 \\
\hline 4 & AVPP0516S & 67.67 & 97.33 & 78.42 & 21.58 & 555.56 & 63.33 & 2.67 & 4.67 \\
\hline 5 & AVPP0517S & 78.67 & 141.67 & 89.17 & 10.83 & 500.00 & 52.00 & 4.33 & 7.67 \\
\hline 6 & AVPP0710S & 72.33 & 124.33 & 93.33 & 6.67 & 666.67 & 58.33 & 2.67 & 5.33 \\
\hline 7 & AVPP0709S & 74.00 & 185.33 & 94.57 & 5.43 & 388.89 & 96.33 & 3.00 & 6.33 \\
\hline 8 & AVPP0711S & 83.00 & 90.33 & 99.00 & 1.00 & 388.89 & 107.33 & 2.67 & 5.00 \\
\hline 9 & AVPP0309 & 68.00 & 125.33 & 9.48 & 90.52 & 4777.78 & 31.67 & 3.33 & 6.00 \\
\hline 10 & AVPP9907 & 76.67 & 139.67 & 15.08 & 84.92 & 15166.67 & 94.00 & 3.67 & 5.67 \\
\hline 11 & VI060629:C05601 & 69.00 & 94.33 & 40.16 & 59.84 & 17266.67 & 66.33 & 2.33 & 4.67 \\
\hline 12 & VI037614:TC0630 & 63.33 & 102.33 & 9.98 & 90.02 & 9388.89 & 73.67 & 3.33 & 5.00 \\
\hline 13 & VI060632:C05661 & 72.33 & 161.67 & 0.00 & 100.00 & 4611.11 & 48.00 & 4.00 & 7.33 \\
\hline 14 & VI046838:TC0667 & 70.00 & 126.33 & 15.43 & 84.57 & 22380.95 & 61.67 & 4.00 & 6.00 \\
\hline 15 & VI060627:C05606 & 72.33 & 94.33 & 11.24 & 88.76 & 18277.78 & 67.00 & 2.67 & 5.67 \\
\hline 16 & VI060630:C05671 & 79.33 & 91.33 & 2.72 & 97.28 & 7555.56 & 102.33 & 2.33 & 4.67 \\
\hline & MEAN & 73.15 & 123.29 & 51.56 & 51.56 & 6464.09 & 69.19 & 3.15 & 5.60 \\
\hline \multicolumn{2}{|r|}{ RANGE } & $\begin{array}{c}63.33 \\
\text { to } 83.00\end{array}$ & $\begin{array}{c}90.33 \text { to } \\
185.33\end{array}$ & $\begin{array}{c}0.00 \text { to } \\
99.00\end{array}$ & $\begin{array}{l}1.00 \text { to } \\
100.00\end{array}$ & $\begin{array}{l}388.89 \text { to } \\
22380.95\end{array}$ & $\begin{array}{c}29.33 \text { to } \\
107.33\end{array}$ & 2.33 to 4.33 & 4.33 to 7.67 \\
\hline & S.D. & 3.81 & 9.17 & 4.20 & 4.20 & 555.97 & 4.94 & 0.63 & 0.87 \\
\hline & C.V. & 5.20 & 7.43 & 8.14 & 8.66 & 8.60 & 7.14 & 20.03 & 15.20 \\
\hline & SE & 2.41 & 6.01 & 3.22 & 3.22 & 441.88 & 3.19 & 0.39 & 0.54 \\
\hline & CD@1\% & 6.95 & 17.31 & 9.28 & 9.28 & 1272.90 & 9.18 & 1.13 & 1.56 \\
\hline
\end{tabular}


Table.2 Time of flower opening of chilli genotypes

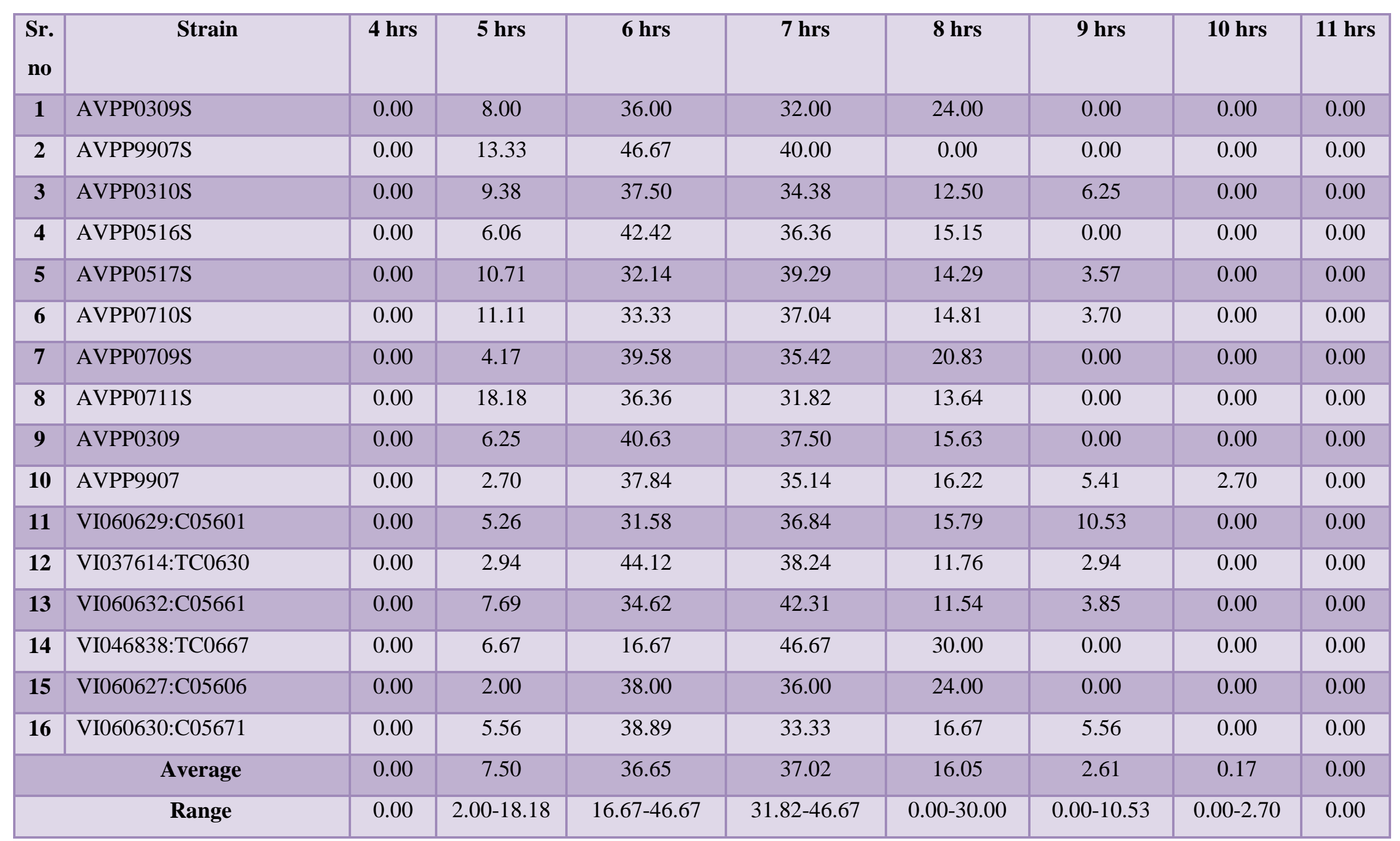




\section{Int.J.Curr.Microbiol.App.Sci (2019) 8(6): 655-661}

Table.3 Time of dehiscence of chilli genotypes




In male sterile lines pollen production ranged from 388.89 to 666.67 and in maintainer lines the pollen production per anther ranged from 4611.11 to 22380.95 . Such results confirmed by Ma et al., (2013) in Pepper (Capasicum annuum L.).

\section{Plant height}

There was a considerable amount of variability among the strains for the plant height. The height of the plant ranged from $29.33 \mathrm{~cm}$ to $107.33 \mathrm{~cm}$. The observation is in line with work of Nwachukwu et al., (2007) and Sahoo et al., (2014) in Capsicum annuum.

\section{Branches per plant}

Stem is erect and branched from the base. In the present investigation, number of primary branches per plant ranged from 2.33 to 4.33 and number of secondary branches per plant ranged from 4.33 to 7.67 , the lines differed significantly for the number of branches per plant. This was in supports with the findings of Sahoo et al., (2014) in chilli.

\section{Opening of flowers}

The data of time of flower opening of chilli genotypes are given in the Table 2. The opening of flowers started at 5.00 a.m., the peak period of opening between 6.00 a.m. to 7.00 a.m.

There was a considerable variability for the opening of flowers amongst the lines studied. Similar results were also reported by Saxena et al., (2003) and Wahua et al., (2014) in chilli (Capasicum annuum L.).

\section{Dehiscence of anthers}

The data of time of dehiscence of chilli genotypes are given in the Table 3 .
Dehiscence occurred after the opening of flowers. Regarding the time of dehiscence of anthers, it was observed that the dehiscence occurred between 7 a.m. to 12 a.m., the peak period of dehiscence being from 8.00 a.m. to 10 a.m. which indicated the need to collect fresh pollen grains during the morning hours.

Similar results were also reported by Saxena et al., (2003) in chilli. Stigma, receptivity: In the present investigation, it was observed that the stigma was sticky and receptive at the time of dehiscence of anthers and it became black in colour 2 days after anthesis. This indicates that pollination may take place upto 2 days after the anthesis. Anim et al., (2006) reported stigma receptivity was from two to four days after anthesis.

\section{Ovary}

All the lines had superiorovary and has axile placentation i.e., ovary is divided into radial segments, with placentas in separate locules. The observation is in line with work of Jagatheeswari (2014) in Solanaceae.

In conclusion, the result showed that wide range of genetic variability existed for the different floral biological characters which could be utilized for systematic exploration in chilli improvement programme through hybridization. Improvement programme would greatly benefit from the knowledge of floral biology gained during the present investigation.

The CMS lines viz., AVPP0711S (99 \%), AVPP0709S (94.57\%), AVPP0710S (93.33 $\%)$, AVPP0309S (92.21\%) and AVPP0310S (90.48 \%) were found to be most sterile. These lines are need to be tested at various seasons and locations to identify most sterile and stable along with other desirable traits before utilizing in heterosis breeding programme. 


\section{References}

Aleemullah, M., Haigh A.M. and Holford P.. 2000. Anthesis, anther dehiscence, pistil receptivity and fruit development in the Longum Group of Capsicum annuum. Australian Journal of Experimental Agriculture 40: 755762.

Anim O.J., Offei S.K., and Yamaki S. 2006. Pistil receptivity, pollen tube growth and gene expression during early fruit development in Sweet Pepper (Capsicum annuum). Int. J. Agri. Biol., Vol. 8, No. 5, 2006.

Jagatheeswari D. 2014. Morphological studies on flowering plants (Solanaceae). International letters of natural sciences vol. 15 (2014) pp 36-43.

Kalloo G. 1994. Vegetable Breeding pp 2223. Panima Educational Book.

Kumar S., Singh V., Singh M., Rai S. K., Kumar S., Rai M. and Kaloo G. 2007. Genetics and distribution of fertility restoration associated RAPD markers in pepper (Capsicum annuum L.).

Hortsci., 111:197-202. Ma Y., Huang W., Ji J.J., Gong Z.H., Yin C.C., Ahmed S.S. and Zhao Z.L. 2013. Maintaining and restoring Cytoplasmic Male Sterility systems in Pepper (Capsicum annuum L.). Genetics and Molecular Research12 (3): 2320-2331 (2013).
Nwachukwu C.U., Mbagwu F.N., Onyeji A. N. 2007. Morphological and Leaf Epidermal features of Capsicum annuum and Capsicum frutescens Solanaceae. Nature and Science, 5(3).

Sahoo L. P., Mohanty S. K. and Rout G.R. 2014. Profiling of 18 cultivars of Capsicum annuum L. using morphological and molecular markers. Acta Advances in Agricultural Sciences Volume 2, Issue 8: 08-17.

Saxena A., Hundai J.S. and Dhall R.K. 2003. Floral biology studies in chilli (Capsicum annuum L.). Veg. Sci. 30(2): 173-175.

Shifriss C.1997. Male sterility in pepper (Capsicum annuum L.) J. Amer Soc. Hort. Sci., 94: 385-387.

Sudré C.P., Gonçalves L.S.A., Rodrigues R., Amaral A.T., Riva-Souza E.M. and Bento C. S. 2010. Genetic variability in domesticated Capsicum spp as assessed by morphological and agronomic data in mixed statistical analysis. Genetics and Molecular Research, 9 (1): 283-294.

Wahua C., Okoli B. E. and Wosu N. L. E. 2014.Morphological, anatomical, cytological and phytochemical studies on Capsicum annuum Linn. (Solanaceae). Euro. J. Exp. Bio., 2014, 4(1):464-471.

\section{How to cite this article:}

Vinodhini, M., V.V. Dalvi, S.S. Desai, S.G. Bhave and Mahadik, S.G. 2019. Floral Biology of CMS Lines in Chilli. Int.J.Curr.Microbiol.App.Sci. 8(06): 655-661. doi: https://doi.org/10.20546/ijcmas.2019.806.076 